\title{
Gamma-secretase: from pathogenesis to therapeutics
}

\author{
Yueming Li \\ From 2011 International Conference on Molecular Neurodegeneration \\ Shanghai, China. 22-24 September 2011
}

\section{Background}

Presenilin (PS) is the catalytic subunit of $\gamma$-secretase and mutations in this protein cause familial Alzheimer's Disease (FAD). Moreover, $\gamma$-secretase has emerged as an appealing drug target for Alzheimer's disease (AD) and cancer due to its central role in the generation of $A \beta$ peptides and the regulation of Notch signaling. $\gamma$-Secretase is composed of at least four subunits: PS, Nicastrin, Aph1 and Pen2; with a total of 19 putative transmembrane domains.

\section{Result}

Investigation of $\gamma$-secretase structure and function has been a formidable challenge because of its nature of intramembranal catalysis and macromolecular complex that requires novel chemical insights. We have developed a reconstituted system and small molecular probes that allow us to study the regulation of $\gamma$-secretase and to elucidate the mechanism of PS1 FAD mutations. We have reconstituted $\gamma$-secretase using a proteoliposomes system and provided the final proof that $\gamma$-secretase activity is an inherent property of PS. Moreover, we have demonstrated that PS mutations directly alter a subsite of $\gamma$-secretase active site and defined the action mechanism of $\gamma$-secretase modulators.

\section{Conclusion}

Our studies provide a molecular basis of PS1 mutations in $\mathrm{AD}$ pathogenesis and offer a unique approach to elucidate the reaction mechanism of $\gamma$-secretase, with the expectation that these efforts will lead to the development of effective therapies for $\mathrm{AD}$ and other human disorders.

Molecular Pharmacology and Chemistry Program, Memorial Sloan-Kettering Cancer Center and Department of Pharmacology, Weill Graduate School of Medical Sciences of Cornell University, New York, USA
Published: 7 February 2012

doi:10.1186/1750-1326-7-S1-L4

Cite this article as: Li: Gamma-secretase: from pathogenesis to therapeutics. Molecular Neurodegeneration 2012 7(Suppl 1):L4.
Submit your next manuscript to BioMed Central and take full advantage of:

- Convenient online submission

- Thorough peer review

- No space constraints or color figure charges

- Immediate publication on acceptance

- Inclusion in PubMed, CAS, Scopus and Google Scholar

- Research which is freely available for redistribution
() Biomed Central
C Biomed Central

(c) 2012 Li; licensee BioMed Central Ltd. This is an Open Access article distributed under the terms of the Creative Commons Attribution License (http://creativecommons.org/licenses/by/2.0), which permits unrestricted use, distribution, and reproduction in any medium, provided the original work is properly cited. 